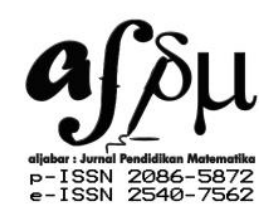

Al-Jabar: Jurnal Pendidikan Matematika

Vol. 6, No. 2, 2015, Hal 131 - 141

\title{
Analisis Kemampuan Komunikasi Matematis dalam Pemecahan Masalah Matematika Sesuai dengan Gaya Kognitif dan Gender
}

\author{
Dona Dinda Pratiwi \\ IAIN Raden Intan Lampung: dindapratiwi_sholeha@yahoo.com
}

Submitted : 20-08-2015, Revised : 09-10-2015, Accepted : 16-12-2015

\begin{abstract}
:
The purpose of this research was describing the ability of mathematical communication in solving the mathematics problem. This research was include of study case situation analysis research. The subjects of this research consisted of four students of Class IXb of the ninth grade SMPN 1 Batanghari in the second semester of the academic year 2012/2013. They were two students who had field dependence cognitive style and two students who had field independence cognitive style. The subjects were taken by using the purposive sampling technique. The data of this research were gathered through think aloud method. The data were then analyzed by using the technique with the procedureas follows: (1) the data were classified on the basis of the indicators of mathematical communication after the data had been obtained from the first and the second collections; (2) the data were presented in table form; and (3) the conclusions were drawn. The validity of the data was conducted by using time triangulation. The result of this research were analyzed by using constant comparison in which subject in $i(i=1,2)$ with the $j(j=1,2)$ cognitive style which was already valid as well compared with subject in $k(k=1,2)$ with the the $j(j=1,2)$ cognitive style which was already valid as well. The equal ability of mathematical communication was made the main finding wheares the different ability of mathematical communication was made the other finding. The result of this research valid because of the dependability proved. The ability of mathematical communication of the students with the field dependence cognitive style is different from that of those with the field independence cognitive style. The students with the field dependence cognitive style can communicate the ideas in written way well but they have difficulties in communicating ideas in spoken way as well as inclination to receive information without reorganizing it in such a way that the problem-solving ideas presented cannot reveal the actual problem solution. Meanwhile, the students with the field independence cognitive style can communicate the ideas well in both spoken and written ways and process as well as reorganize information in such a way that the problem-solving ideas presented can reveal the actual problem solution.
\end{abstract}

Kata Kunci: Cognitive; Communication; Gender; Problem; Solving.

\begin{abstract}
Abstrak
Tujuan dari penelitian ini adalah mendeskripsikan kemampuan komunikasi matematis dalam memecahkan masalah matematika. Penelitian ini meliputi penelitian analisis kasus kasus studi kasus. Subjek penelitian ini terdiri dari empat siswa kelas IXb kelas 9 SMPN 1 Batanghari pada semester kedua tahun ajaran 2012/2013. Mereka adalah dua siswa yang memiliki gaya
\end{abstract}




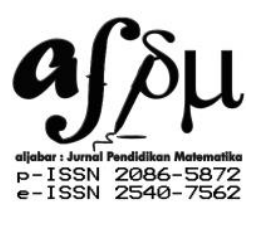

kognitif medan ketergantungan dan dua siswa yang memiliki gaya kognitif lapangan. Subyek diambil dengan teknik purposive sampling. Data penelitian ini dikumpulkan melalui metode berpikir keras. Data kemudian dianalisis dengan menggunakan teknik dengan prosedurnya sebagai berikut: (1) data diklasifikasikan berdasarkan indikator komunikasi matematis setelah data diperoleh dari koleksi pertama dan kedua; (2) data disajikan dalam bentuk tabel; Dan (3) kesimpulan ditarik. Validitas data dilakukan dengan menggunakan triangulasi waktu. Hasil penelitian ini dianalisis dengan menggunakan perbandingan konstan dimana subjek pada i ( $\mathrm{i}=$ $1,2)$ dengan gaya $\operatorname{kognitif} j(j=1,2)$ yang telah valid dan dibandingkan dengan subjek $k(k=1$ , 2) dengan gaya kognitif $j(j=1,2)$ yang sudah valid juga. Kemampuan komunikasi matematis yang sama dijadikan temuan utama yang membalikkan kemampuan komunikasi matematis yang berbeda dijadikan temuan lainnya. Hasil penelitian ini valid karena terbukti kehandalannya. Kemampuan komunikasi matematis siswa dengan gaya ketergantungan kognitif di lapangan berbeda dengan gaya kognitif lapangan yang independen. Para siswa dengan gaya ketergantungan kognitif di lapangan dapat mengkomunikasikan gagasan dengan cara tertulis dengan baik namun mereka mengalami kesulitan dalam mengkomunikasikan gagasan dengan cara lisan serta kecenderungan untuk menerima informasi tanpa menata ulangnya sedemikian rupa sehingga gagasan pemecahan masalah yang disajikan tidak dapat mengungkapkan Solusi masalah sebenarnya Sementara itu, siswa dengan gaya kognitif lapangan dapat mengkomunikasikan ide dengan baik baik lisan maupun tulisan serta proses pengorganisasian serta menata ulang informasi sedemikian rupa sehingga ide pemecahan masalah yang disajikan dapat mengungkapkan solusi permasalahan yang sebenarnya.

Kata Kunci: Kelamin; Kognitif; Komunikasi; Problem; Solving.

\section{PENDAHULUAN}

Komunikasi matematis adalah cara untuk menyampaikan ide-ide pemecahan masalah, strategi maupun solusi matematika baik secara tertulis maupun lisan. Sedangkan, kemampuan komunikasi matematis dalam pemecahan masalah menurut National Council of Teachers of Mathematics (2000:348) dapat dilihat ketika siswa menganalisis dan menilai pemikiran dan strategi matematis orang lain dan menggunakan bahasa matematika untuk menyatakan ide matematika dengan tepat.

Melalui komunikasi, siswa dapat mengeksplorasi dan mengonsolidasikan pemikiran matematisnya, pengetahuan dan pengembangan dalam memecahkan masalah dengan penggunaan bahasa matematis dapat dikembangkan, sehingga komunikasi matematis dapat dibentuk.

Begitu juga menurut hasil penelitian Osterholm (2006:292-294) menyatakan bahwa siswa tampaknya kesulitan mengartikulasikan alasan dalam memahami suatu bacaan. Masih banyaknya siswa yang tidak menuliskan solusi tersebut menjadikan komunikasi intrapersonal (pemrosesan simbol pesan-pesan) dan interpersonal (proses penyampaian pesan) penting dalam menginterpretasikan istilah untuk memecahkan masalah matematika.

Terkait dengan hal tersebut, cara siswa dapat berbeda dalam memproses simbol pesanpesan, menyimpan, dan menggunakan informasi untuk menanggapi suatu tugas. Hal tersebut sesuai dengan pendapat Wolfe \& Johnson dalam Oh \& Lim (2005:54) yang menyatakan bahwa seseorang memiliki cara yang berbeda dalam mencari dan memproses informasi, 
serta melihat dan menginterpretasikannya. Perbedaan cara seseorang dalam memproses informasi tersebut lebih dikenal dengan gaya kognitif (keefe dalam Oh \& Lim, 2005:54).

Ada banyak tipe gaya kognitif, salah satu tipe yang sering digunakan adalah gaya kognitif menurut Witkin, Oltman, Raskin, dan Karp dalam Oh dan Lim (2005:54) yaitu gaya kognitif Field Dependence (FD) dan Field Independence (FI). Karakteristik individu dengan gaya kognitif FD lebih suka menyelesaikan sesuatu dengan cara yang telah ditetapkan, sedangkan individu Fl lebih menyukai penyelesaian tidak linear (Bilal Atasoy, Guyer Tolga, dan Sibel Somyurek, 2008:33-40). Hal ini menunjukkan bahwa individu dengan gaya kognitif Fl lebih baik dari individu FD.

Bahkan hasil penelitian Tri Dyah Prastiti (2009) tentang implementasi Realistic Mathematics Education (RME) dengan memperhatikan gaya kognitif siswa dan peng a ruhnya terhadap kemampuan komunikasi dan pemecahan masalah matematika SMP menyimpulkan bahwa siswa dengan gaya kognitif Fl lebih baik daripada siswa dengan gaya kognitif FD dalam kemampuan komunikasi matematis dan pemecahan masalah matematika. Meskipun demikian, berdasarkan karakteristik dua gaya kognitif FD dan FI tidak dapat disimpulkan bahwa salah satunya lebih unggul karena dari karakteristik kedua gaya kognitif tersebut, masing-masing mempunyai kelebihan dan kekurangan.

Selain itu, faktor gender juga dapat mempengaruhi cara seseorang dalam menyelesaikan masalah. Seperti hasil penelitian Zubaidah Amir, bahwa terdapat perbedaan kemampuan matematika siswa dari aspek gender. Gender dalam penelitian ini hanya sebatas pada identitas gender, yaitu perbedaan jenis antara kelamin laki-laki dan perempuan.

Dari hasil kajian di atas, perlu diteliti lebih dalam lagi bagaimana kemampuan komunikasi matematis dalam pemecahan masalah matematika pada siswa SMP kelas IX yang memiliki gaya kognitif FD dan FI serta gender yang berbeda.

\section{METODE PENELITIAN}

Jenis penelitian ini adalah penelitian studi kasus analisis situasi. Penelitian ini dilaksanakan di SMP Negeri 1 Batanghari pada semester genap tahun pelajaran 2013/2014. Subjek penelitian adalah subjek FD1 (laki-laki) dan FD2 (perempuan) yang memiliki gaya kognitif field dependence serta subjek FI1 (laki-laki) dan FI2 (perempuan) yang memiliki gaya kognitif field independence. Penentuan subjek dipilih dengan menggunakan tes gaya kognitif GEFT. Pengambilan subjek menggunakan teknik purposive sampling, caranya subjek dicari sesuai dengan kriteria. Adapun kriteria tersebut sebagai berikut:

1. Dapat mengomunikasikan ide dengan baik secara tertulis atau lisan

2. Memiliki kemampuan awal yang sama untuk masing-masing tipe gaya kognitif. Pemilihan subjek sesuai dengan kriteria diperoleh dari informasi guru matematika di kelas IXb.

Teknik pengumpulan data pada penelitian ini menggunakan metode think aloud method yaitu subjek diminta untuk mengungkapkan kemampuan komunikasi matematis pada saat pemecahan masalah secara tertulis atau lisan. Think aloud method dalam penelitian ini direkam dengan alat bantu berupa handycam. Hasil analisis data dari masing-masing subjek pada tes pemecahan masalah I dan II ditriangulasi waktu untuk mendapatkan data yang valid. 


\section{HASIL PENELITIAN DAN PEMBAHASAN}

Kemampuan komunikasi matematis yang sama merupakan temuan utama penelitian dan jika terdapat kemampuan komunikasi matematis yang berbeda, maka menjadi temuan lain dalam penelitian. Kemampuan komunikasi matematis dari subjek FD1 dan FD2 dapat dilihat pada Tabel 1 sebagai berikut.

Tabel 1. Perbandingan Kemampuan Komunikasi Matematis Subjek FD1 dan FD2

\begin{tabular}{|c|c|c|}
\hline $\begin{array}{c}\text { Indikator } \\
\text { Kom unikasi Matematis } \\
\end{array}$ & Data Valid Subjek FD1 & Data Valid Subjek FD2 \\
\hline $\begin{array}{l}\text { 1. Menginterpretasikan ide } \\
\text { matematis. }\end{array}$ & $\begin{array}{l}\text { a. Dapat memahami } \\
\text { masalah secara } \\
\text { keseluruhan. } \\
\text { b. Dapat menyatakan } \\
\text { langkah pemecahan } \\
\text { masalah dengan cara } \\
\text { mencoba-coba dan } \\
\text { terpola. } \\
\text { c. Dapat merespon } \\
\text { secara lisan, namun } \\
\text { sulit dipahami. }\end{array}$ & $\begin{array}{l}\text { a. Dapat memahami } \\
\text { masalah secara } \\
\text { keseluruhan. } \\
\text { b. Dapat menyatakan } \\
\text { langkah pemecahan } \\
\text { masalah dengan baik, } \\
\text { namun masih bersifat } \\
\text { umum. } \\
\text { c. Dapat merespon } \\
\text { secara lisan dengan } \\
\text { cukup baik. }\end{array}$ \\
\hline $\begin{array}{l}\text { 2. Menggambarkan situasi } \\
\text { masalah dalam bentuk } \\
\text { visual. }\end{array}$ & $\begin{array}{l}\text { a. Dapat menggambar } \\
\text { berdasarkan } \\
\text { informasi pada soal } \\
\text { tanpa menganalisis } \\
\text { permasalahan yang } \\
\text { sebenarnya dan } \\
\text { tidak sesuai dengan } \\
\text { langkah pemecahan } \\
\text { masalah. } \\
\text { b. Dapat } \\
\text { mengaplikasikan } \\
\text { konsep geometri } \\
\text { dalam menentukan } \\
\text { posisi namun tidak } \\
\text { tepat. } \\
\text { c. Dapat } \\
\text { mengomunikasikan } \\
\text { ide secara tertulis } \\
\text { namun sulit } \\
\text { mengomunikasikan } \\
\text { ide secara lisan. }\end{array}$ & $\begin{array}{l}\text { a. Dapat menggambar } \\
\text { berdasarkan informasi } \\
\text { pada soal tanpa } \\
\text { menganalisis } \\
\text { permasalahan yang } \\
\text { sebenarnya dan sesuai } \\
\text { dengan langkah } \\
\text { pemecahan masalah } \\
\text { namun belum sampai } \\
\text { pada pemecahan } \\
\text { masalah yang } \\
\text { diharapkan. } \\
\text { b. Dapat } \\
\text { mengaplikasikan } \\
\text { konsep geometri } \\
\text { dalam menentukan } \\
\text { posisi namun tidak } \\
\text { tepat. } \\
\text { c. Dapat } \\
\text { mengomunikasikan } \\
\text { ide tertulis dengan } \\
\text { baik namun sulit } \\
\text { mengomunikasikan } \\
\text { ide secara lisan. }\end{array}$ \\
\hline
\end{tabular}




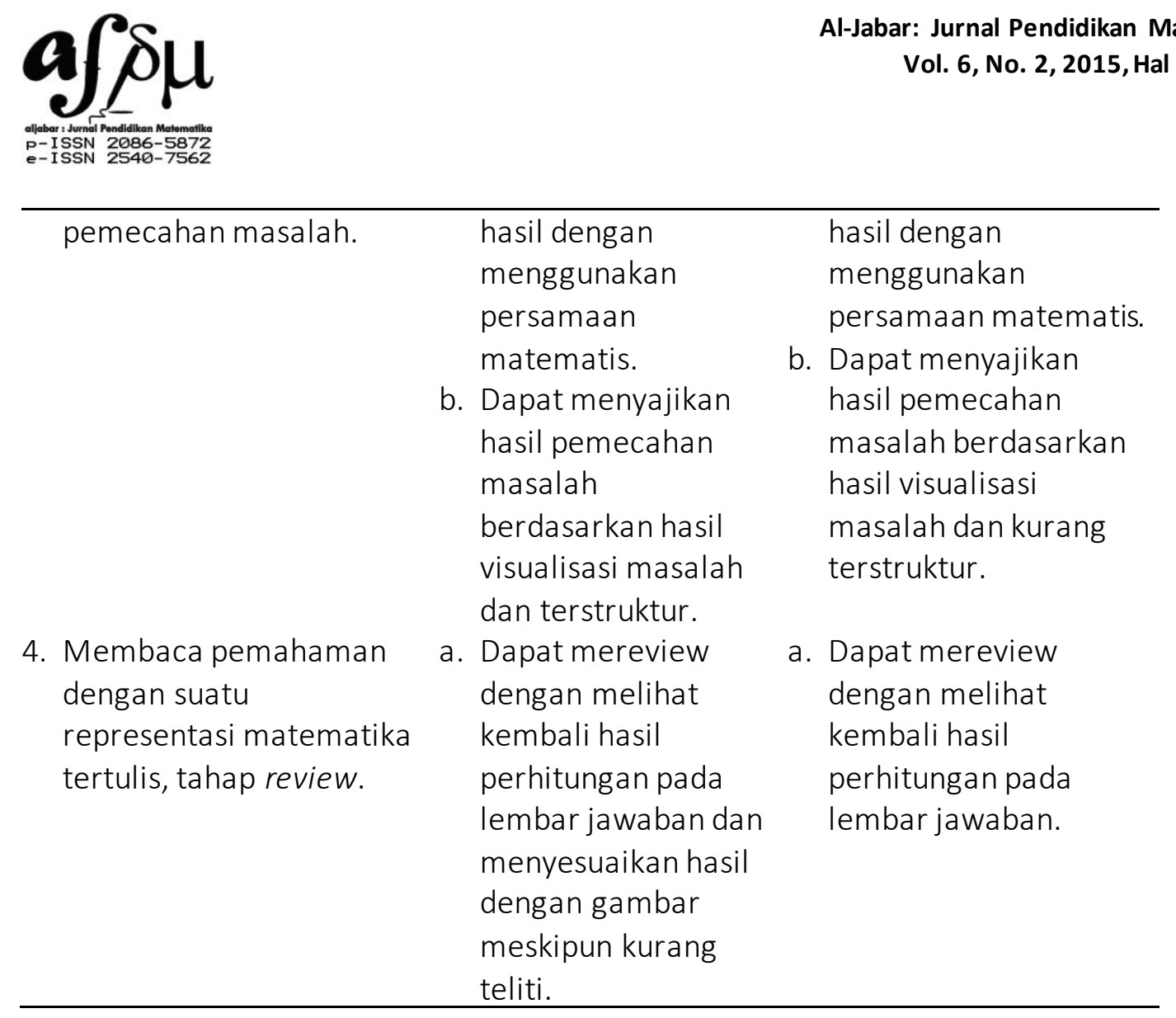

Dari Tabel 1 di atas terlihat ada kesamaan dalam keempat indikator, yaitu:

1. Menginterpretasikan Ide matematis

Siswa FD1 dan FD2 memiliki persamaan dalam hal memahami masalah secara keseluruhan. Namun berbeda ketika menyatakan langkah pemecahan masalah, siswa FD1 menyelesaikan masalah lebih terpola dengan cara mencoba-coba. Kemudian siswa FD1 lebih dapat merespon secara lisan, namun sulit dipahami. Berbeda dengan siswa FD2 dapat menyatakan langkah pemecahan masalah dengan baik, namun masih bersifat umum dan dapat merespon secara lisan dengan cukup baik.

2. Menggambarkan situasi masalah dalam bentuk visual.

Siswa FD1 dan FD2 memiliki persamaan dalam hal menggambarkan masalah, mereka dapat mengaplikasikan konsep geometri dalam menentukan posisi namun tidak tepat dan mengomunikasikan ide secara tertulis namun sulit mengomunikasikan secara lisan. Namun berbeda dengan siswa FD1 dapat membuat gambar berdasarkan informasi pada soal tanpa menganalisis permasalahan yang sebenarnya dan tidak sesuai dengan langkah pemecahan masalah. Sedangkan siswa FD2 dapat membuat gambar berdasarkan informasi pada soal tanpa menganalisis permasalahan yang sebenarnya dan sesuai dengan langkah pemecahan masalah namun belum sampai pada peme-cahan masalah yang diharapkan.

3. Menyatakan hasil pemecahan masalah.

Siswa FD1 dan FD2 memiliki persamaan dalam hal menyatakan hasil pemecahan masalah yaitu dengan menggunakan persamaan matematis.

Namun sedikit berbeda dalam penyajiannya, siswa FD1 menyajikan hasil pemecahan masalah berdasarkan hasil visualisasi masalah dan terstruktur. Sedangkan FD2 dapat menyajikan hasil pemecahan masalah berdasarkan hasil visualisasi masalah dan kurang terstruktur. 
4. Membaca pemahaman dengan suatu representasi matematika tertulis, tahap review.

Siswa FD1 dan FD2 memiliki persamaan dalam hal membaca pemahaman dapat mereview dengan memeriksa hasil perhitungan. Namun berbeda dalam melihat kembali hasil perhitungan, siswa FD1 dapat mereview dengan melihat kembali hasil perhitungan pada lembar jawaban dan menyesuaikan hasil dengan gambar meskipun kurang teliti. Sedangkan siswa FD2 dapat mereview dengan melihat kembali hasil perhitungan pada lembar jawaban.

Kemudian kemampuan komunikasi matematis siswa FI1 dan Fl2 dapat dilihat pada Tabel 2 berikut.

Tabel 2. Perbandingan Kemampuan Komunikasi Matematis Subjek FI1 dan FI2

\begin{tabular}{|c|c|c|}
\hline $\begin{array}{c}\text { Indikator } \\
\text { Kom unikasi Matematis }\end{array}$ & Data Valid Subjek FI1 & Data Valid Subjek FI2 \\
\hline $\begin{array}{l}\text { 1. Menginterpretasikan ide } \\
\text { matematis. }\end{array}$ & $\begin{array}{l}\text { a. Dapat memahami } \\
\text { masalah secara } \\
\text { terpisah. } \\
\text { b. Dapat menyatakan } \\
\text { langkah pemecahan } \\
\text { masalah dengan baik. } \\
\text { c. Dapat memberikan } \\
\text { respon secara lisan } \\
\text { dengan jelas. }\end{array}$ & $\begin{array}{l}\text { a. Dapat memahami } \\
\text { masalah secara } \\
\text { terpisah. } \\
\text { b. Dapat menyatakan } \\
\text { langkah pemecahan } \\
\text { masalah dengan } \\
\text { tepat. } \\
\text { c. Dapat memberikan } \\
\text { respon secara lisan } \\
\text { dengan jelas. }\end{array}$ \\
\hline $\begin{array}{l}\text { 2. Menggambarkan situasi } \\
\text { masalah dalam bentuk } \\
\text { visual. }\end{array}$ & $\begin{array}{l}\text { a. Dapat membuat } \\
\text { gambar berdasarkan } \\
\text { analisis dan sesuai } \\
\text { dengan langkah } \\
\text { pemecahan masalah } \\
\text { dengan tepat. } \\
\text { b. Dapat } \\
\text { mengaplikasikan } \\
\text { konsep geometri } \\
\text { dalam menentukan } \\
\text { posisi untuk } \\
\text { pemecahan masalah } \\
\text { dengan baik dan } \\
\text { pengaplikasiannya } \\
\text { cenderung mencoba- } \\
\text { coba. } \\
\text { c. Dapat } \\
\text { mengomunikasikan } \\
\text { ide tertulis dan lisan } \\
\text { dengan baik. }\end{array}$ & $\begin{array}{l}\text { a. Dapat membuat } \\
\text { gambar berdasarkan } \\
\text { analisis dan sesuai } \\
\text { dengan langkah } \\
\text { pemecahan masalah } \\
\text { dengan tepat. } \\
\text { b. Dapat } \\
\text { mengaplikasikan } \\
\text { konsep geometri } \\
\text { dalam menentukan } \\
\text { posisi untuk } \\
\text { pemecahan masalah } \\
\text { dengan tepat dan } \\
\text { disertai aplikasi } \\
\text { gambar lain untuk } \\
\text { meyakinkan jawaban. } \\
\text { c. Dapat } \\
\text { mengomunikasikan } \\
\text { ide tertulis dan lisan } \\
\text { dengan baik. }\end{array}$ \\
\hline $\begin{array}{l}\text { 3. Menyatakan hasil } \\
\text { pemecahan masalah. }\end{array}$ & $\begin{array}{l}\text { a. Dapat menyatakan } \\
\text { hasil dengan }\end{array}$ & $\begin{array}{l}\text { a. Dapat menyatakan } \\
\text { hasil dengan }\end{array}$ \\
\hline
\end{tabular}




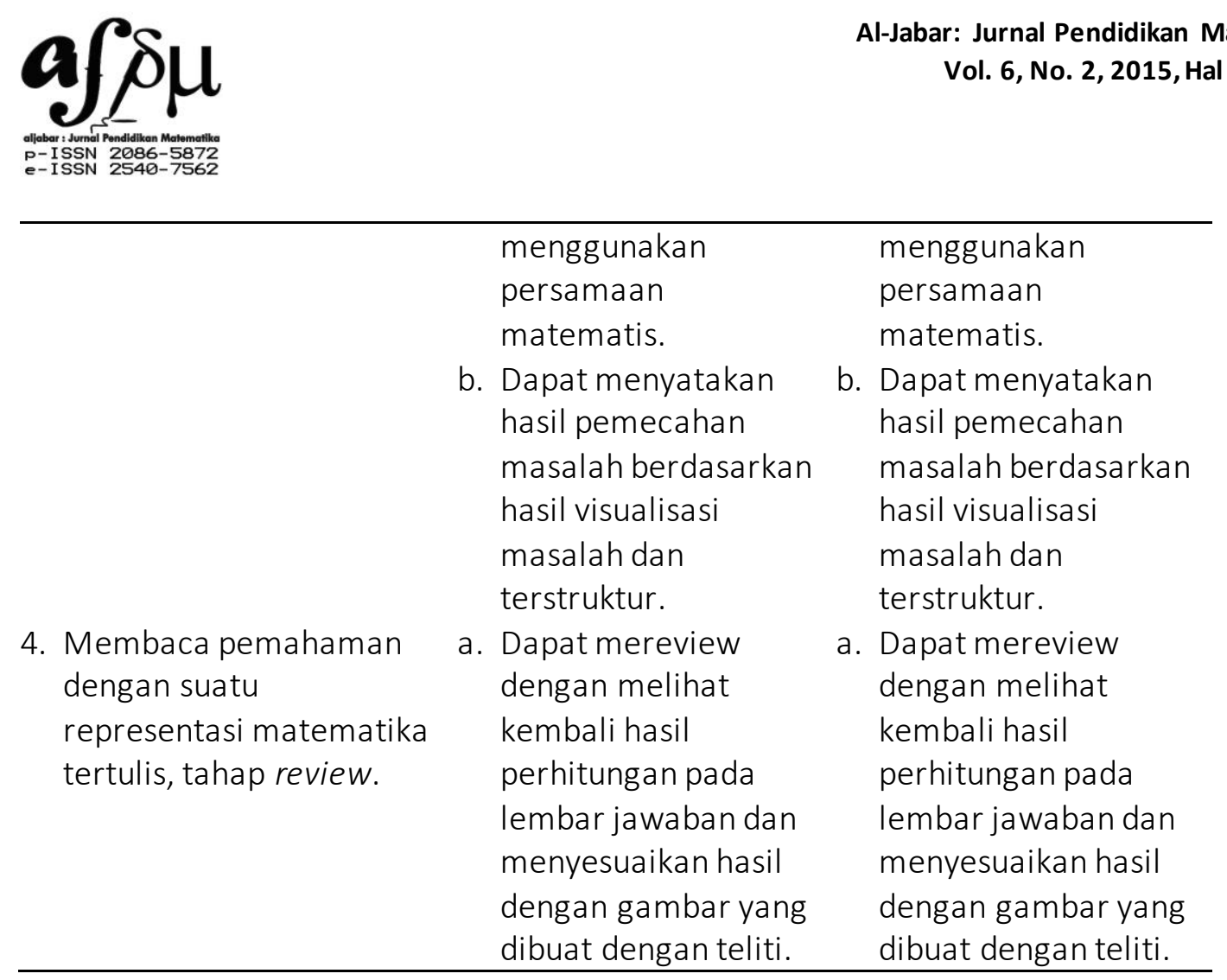

Dari Tabel 2 di atas terlihat ada kesamaan dalam keempat indikator, yaitu:

1. Menginterpretasikan Ide matematis

Siswa Fl1 dan Fl2 memiliki persamaan dalam memahami masalah yaitu dengan cara terpisah dan dapat memberikan respon secara lisan dengan jelas. Siswa Fl1 dapat menyatakan langkah pemecahan masalah dengan baik, namun siswa FI2 tidak hanya baik namun juga menyatakan dengan tepat.

2. Menggambarkan situasi masalah dalam bentuk visual.

Siswa Fl1 dan Fl2 memiliki persamaan dalam hal membuat gambar berdasarkan analisis dengan tepat dan sesuai dengan langkah pemecahan masalah serta dapat mengomunikasikan ide tertulis dan lisan dengan baik. Siswa FI1 dapat mengaplikasikan konsep geometri dalam menentukan posisi untuk pemecahan masalah dengan baik dan pengaplikasiannya cenderung mencoba-coba. Sedangkan siswa Fl2 mengaplikasikan konsep geometri dalam menentukan posisi untuk pemecahan masalah dengan tepat dan disertai aplikasi gambar lain untuk meyakinkan jawaban.

3. Menyatakan hasil pemecahan masalah.

Siswa Fl1 dan Fl2 dapat menyatakan hasil dengan menggunakan persamaan matematis dan menyajikan hasil pemecahan masalah berdasarkan hasil visualisasi masalah dan terstruktur.

4. Membaca pemahaman dengan suatu representasi matematika tertulis, tahap review.

Siswa Fl1 dan FI2 dapat mereview dengan melihat kembali hasil perhitungan pada lembar jawaban dan menyesuaikan dengan gambar yang dibuat dengan teliti.

Berdasarkan hasil kemampuan komunikasi matematis pada Tabel 1 dan Tabel 2, dapat dirumuskan persamaan dan perbedaan kemampuan komunikasi matematis antara siswa FD dan Fl secara tertulis atau lisan dari masing-masing indikator sebagai berikut.

1. Menginterpretasikan Ide Matematis. 
Siswa FD dan FI memiliki persamaan dalam memahami dan menginterpretasikan ide matematika yaitu sudah memahami masalah dengan baik, hanya saja cara dalam memahami masalah berbeda. Siswa FD lebih memahami masalah secara keseluruhan, sedangkan siswa FI lebih memahami masalah secara terpisah. Hal ini sesuai dengan karakteristik gaya kognitif FD yang lebih memandang objek secara global dan menyatu dengan lingkungan sekitar, sedangkan karakteristik gaya kognitif Fl memandang objek terdiri dari bagian-bagian diskrit dan terpisah dari lingkungan. Selain itu, siswa FD menyatakan langkah pemecahan masalah dengan mencoba-coba dan terpola, ada juga siswa FD yang sudah menyatakan langkah pemecahan masalah dengan baik namun masih bersifat umum, artinya langkah pemecahan masalah yang diberikan berdasarkan informasi yang tersaji pada soal tanpa menganalisis permasalahan yang sebenarnya. Siswa FD juga memberikan respon secara lisan, nam un sulit untuk dipahami dan cenderung kurang jelas serta tidak efisien. Ada juga siswa FD yang merespon secara lisan dengan cukup baik meskipun masih bersifat umum. Hal ini sesuai dengan karakteristik gaya kognitif FD yang cenderung hanya menerima informasi, sehingga tidak mampu mengorganisir informasi kembali untuk diungkapkan kepada orang lain.

Berbeda dengan siswa FD, siswa FI menyatakan langkah pemecahan masalah dengan baik dan ada yang menyajikan langkah pemecahan masalah dengan tepat, respon secara lisan juga jelas. Hal ini sesuai dengan karakteristik gaya kognitif FI yang mampu mengorganisasi masalah yang belum terorganisir serta mereorganisasi masalah yang sudah terorganisir, sehingga siswa Fl dapat merespon secara lisan dengan argumen yang jelas.

2. Menggambarkan Situasi Masalah Dalam Bentuk Visual.

Siswa FD tidak memiliki persamaan dengan siswa Fl pada saat menggambarkan situasi masalah dalam bentuk visual. Hal ini terlihat ketika siswa FD menggambarkan situasi masalah berdasarkan informasi pada soal tanpa menganalisis permasalahan yang sebenarnya dan tidak sesuai dengan langkah pemecahan masalah, ada juga yang sudah sesuai dengan langkah pemecahan masalah namun belum sampai pada pemecahan masalah yang diharapkan. Siswa FD mengaplikasikan konsep geometri dalam menentukan posisi dengan tidak tepat dan dapat mengomunikasikan ide secara tertulis namun sulit mengomunikasikan ide secara lisan. Hal ini sesuai dengan karakteristik gaya kognitif FD yang kesulitan memproses informasi dan cenderung hanya menerima informasi yang disajikan tanpa mengorganisasi kembali sehingga sulit menggambarkan situasi masalah melalui gambar.

Berbeda dengan siswa FD, siswa FI membuat gambar dengan menganalisis informasi yang disajikan dan sesuai dengan langkah pemecahan masalah dengan tepat, mengaplikasikan konsep geometri dalam menentukan posisi untuk pemecahan masalah dengan baik dan pengaplikasiannya cenderung mencoba-coba atau ada yang mengaplikasikan konsep disertai aplikasi gambar lain untuk menyakinkan jawaban dan dapat mengomunikasikan ide tertulis dan lisan dengan baik. Meskipun, keduanya berbeda pada saat mengaplikasikan konsep geometri, namun keduanya sudah pada pemecahan masalah yang sebenarnya. Hal ini sesuai dengan karakteristik gaya kognitif Fl yang mampu memproses informasi dan mengorganisasi objek yang belum terorganisir dan mereorganisasi objek yang sudah terorganisir.

3. Menyatakan Hasil Pemecahan Masalah.

Siswa FD dan FI terlihat memiliki kesamaan dalam menyatakan hasil pemecahan masalah, yaitu: dengan menggunakan persamaan matematis dan menyajikan hasil 
pemecahan masalah berdasarkan hasil visualisasi masalah. Namun, siswa FD menyajikan hasil secara terstruktur atau ada juga yang kurang terstruktur, sedangkan siswa FI menyajikan hasil secara terstruktur. Hal ini sesuai dengan karakteristik gaya kognitif FD yang sulit fokus pada satu aspek dan menganalisis pola menjadi bagian yang berbeda, sedangkan karakteristik gaya kognitif $\mathrm{Fl}$ yang menunjukkan bagian-bagian terpisah dari pola keseluruhan dan mampu menganalisis pola ke dalam komponen-komponennya.

4. Membaca Pemahaman dengan Suatu Representasi Matematika Tertulis.

Siswa FD dan FI terlihat memiliki perbedaan dalam membaca pemahaman dengan suatu representasi matematika tertulis pada tahap review, yaitu memeriksa jawaban. Siswa FD memeriksa jawaban dengan melihat kembali hasil perhitungan pada lembar jawaban dan menyesuaikan hasil dengan gambar meskipun kurang teliti, sedangkan siswa Fl memeriksa hasil perhitungan sesuai dengan gambar dan teliti. Maksud dari ketidaktelitian ini bahwa a da sebagian dari hasil pemecahan masalah yang tidak diperiksa dengan baik, sehingga masih terdapat kesalahan pada proses perhitungan. Hal ini bisa disebabkan dari cara siswa FD yang menyajikan hasil pemecahan masalah menjadi bagian yang berbeda, dalam arti bagian yang berbeda tersebut adalah pola pemecahan masalah dari keseluruhan hasil. Hal ini sesuai dengan karakteristik gaya kognitif FD yang sulit fokus pada satu aspek dan menganalisis pola menjadi bagian yang berbeda, sedangkan karakteristik gaya kognitif $\mathrm{Fl}$ yang mampu menunjukkan bagian-bagian terpisah dari pola menyeluruh dan mampu menganalisis pola ke dalam komponen-komponennya.

Hasil analisis pada siswa FD sesuai dengan teori Witkin yang menyatakan bahwa gaya kognitif FD memiliki karaktersitik sebagai berikut: kesulitan memproses informasi, cenderung hanya menerima informasi yang diberikan dan tidak mampu mengorganisasi kembali, persepsi kuat ketika dimanipulasi sesuai konteksnya namun lemah ketika terjadi perubahan konteks, sulit fokus pada satu aspek cenderung mengikuti tujuan yang sudah ada, menganalisis pola menjadi bagian-bagian yang berbeda, serta memandang objek secara global dan menyatu dengan lingkungan sekitar.

Hasil analisis pada siswa Fl sesuai dengan teori Witkin (1997) yang menyatakan bahwa gaya kognitif $\mathrm{Fl}$ memiliki karakteristik sebagai berikut: berpikir secara analitis dan mampu memproses informasi, mampu mengorganisasi objek yang belum terorganisir dan mereorganisasi objek yang sudah terorganisir, serta dapat menganalisis untuk memisahkan objek dari lingkungan sekitar sehingga persepsi tidak terpengaruh jika terjadi perubahan konteks dan menunjukkan bagian-bagian terpisah dari pola keseluruhan dan mampu menganalisis pola ke dalam komponen-komponennya.

\section{SIMPULAN DAN SARAN}

Berdasarkan hasil analisis data dan pembahasan 4 subjek penelitian pada siswa kelas IX SMP Negeri 1 Batanghari diperoleh kesimpulan kemampuan komunikasi matematis dalam pemecahan masalah matematika sebagai berikut.

1. Field Dependence (FD)

Kemampuan komunikasi matematis siswa FD dengan gender yang berbeda tidak memiliki banyak perbedaan. Siswa FD1 dalam indikator pertama dan ketiga terlihat sama. Dalam indikator pertama, siswa FD1 dan FD2 dapat memahami masalah secara keseluruhan dan menyatakan langkah pemecahan masalah dengan cara mencoba-coba dan terpola atau 


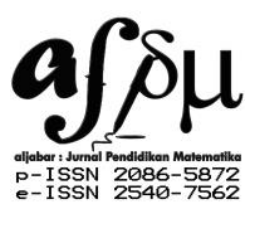

menyatakan langkah pemecahan masalah dengan baik namun masih bersifat umum. Dalam indikator ketiga menyatakan hasil pemecahan masalah dengan menggunakan persamaan matematis dan menyajikan hasil pemecahan masalah berdasarkan hasil visualisasi masalah dengan terstruktur atau kurang terstruktur. Dalam indikator keempat, baik siswa FD1 dan FD2 membaca dengan pemahaman suatu representasi matematika tertulis pada tahap review dengan cara melihat kembali hasil perhitungan dan menyesuaikan dengan gambar namun kurang teliti. Sedangkan perbedaan yang nampak jelas terlihat pada indikator kedua. Siswa FD1 menggambarkan situasi masalah secara visual dengan mengaplikasikan konsep geometri dalam menentukan posisi namun tidak tepat, dapat mengomunikasikan ide secara tertulis namun sulit mengomunikasikan ide secara lisan, sedangkan FD2 menggambar masalah berdasarkan informasi pada soal tanpa menganalisis permasalahan yang sebenarnya dan tidak sesuai dengan langkah pemecahan masalah atau ada yang sudah sesuai dengan langkah pemecahan masalah namun belum sampai pada pemecahan masalah yang diharapkan.

\section{Field Independence (FI)}

Kemampuan komunikasi matematis siswa $\mathrm{Fl}$ dengan gender yang berbeda juga tidak memiliki banyak perbedaan. Pada indikator pertama, ketiga, dan keempat tidak terlihat adanya perbedaan pada siswa FI1 dan Fl2, yaitu dalam menginterpretasikan ide matematis dapat memahami masalah secara terpisah dan menyatakan langkah pemecahan masalah dengan baik atau dengan baik dan tepat dan memberikan respon secara lisan dengan jelas, dapat menyatakan hasil pemecahan masalah dengan menggunakan persamaan matematis dan menyajikan hasil pemecahan masalah berdasarkan hasil visualisasi masalah dengan terstruktur atau kurang terstruktur. Dalam membaca pemahaman suatu representasi matematika tertulis dengan cara melihat kembali hasil perhitungan dan menyesuaikan hasil dengan gambar dan teliti. Pada indikator kedua, siswa Fl2 dalam menggambarkan situasi masalah secara visual dapat menggambar berdasarkan analisis dengan tepat dan sesuai dengan langkah pemecahan masalah, mengaplikasikan konsep geometri dalam menentukan posisi untuk pemecahan masalah dengan baik dan sedangkan Fl1 pengaplikasiannya cenderung mencoba-coba atau menyertakan4 aplikasi gambar lain untuk meyakinkan jawaban, dapat mengomunikasikan ide tertulis dan lisan dengan baik.

\section{DAFTAR PUSTAKA}

Bistari, BsY. (2010). Pengembangan Kemandirian Belajar Berbasis Nilai Untuk Meningkatkan Komunikasi Matematik. Jurnal Pendidikan Matematika dan IPA Vol. 1, No. 1, 11-23.

Gusni Satriawati. 2006. Pembelajaran Dengan Pendekatan Open Ended Untuk Meningkakan Pemahaman dan Kemampuan Komunikasi Matematika Siswa SMP Jakarta (Studi eksperimen di SMP Bakti Mulya 400 Jakarta Selatan). Tesis Pascasarjana Pendidikan Matematika UPI. Bandung. Tidak diterbitkan.

Hirscfeld, K. (2008). Mathematical communication, Conceptual Understanding, and Students' Attitudes Toward mathematics. Math in the Middle Institute Partnership Action Research Project Report. University of Nebraska-Lincoln. 
National Council of Teachers of Mathematics (NCTM). (2000). Principles and Standard for School mathematics. Virginia: NCTM inc.

Maryani, N. (2011). Pencapaian kemampuan komunikasi matematis siswa melalui pembelajaran dengan strategi SQ3R (studi eksperimen SMA Negeri kabupaten garut). Tesis UPI: Tidak diterbitkan.

Oh, E \& Lim, D. (2005). Cross Relantionships Between Cognitive Styles and Learner Variables in Online Learning Environment. Journal of Interaktive Online Learning Vol. 4, No. 1, 53-66.

Osterholm, M. (2006). Metakognition and reading-criteria for comprehension of mathematics texts. In Novotna, J., Moraova, H., Kratka, M. \& Stehlikova, N. (Eds.). Proceedings 30th Conference of the Internatinal Group for the Psychology of Mathematics Education, Vol. 4, 289-296.

Somyurek, S., Guyer, T., Atasoy, B. (2008). The Effect of Individual Differeces on Learner's Navigation in a Courseware. The Turkish Online Journal of Educatinal Technology Vol. 7, issue 2 article 4, 32-40.

Prastiti, T.D. (2009). Implementasi Mathematics Education Dengan Memperhatikan Gaya Kognitif Siswa dan Pengaruhnya Terhadap Kemampuan Komunikasi dan Pemecahan Masalah Matematika SMP. Jurnal Pendidikan dan Pembelajaran (JPP), Vol. 16, No. 1.

Witkin, H. A., Moore, C. A., Goodenough, D. R., dan Cox, P. W. (1977). Field-dependent and Field-independent Cognitive Style and their Educational Implications. Reviews of educational Research Vol 4 No 7, 1-64. 